\title{
THE USE OF MODERN EXPERT SYSTEMS IN THE ECONOMIC ENVIRONMENT OF THE COUNTRY
}

\author{
Anna Starukh ${ }^{1}$ \\ DOI: https://doi.org/10.30525/978-9934-588-38-9-35
}

\begin{abstract}
The article deals with the current aspects of the modern expert systems application in the economic environment of the country. The research relevance is determined by the focus on the solving complex problems and providing users with high-level problem-solving tools. The subject of the study is expert systems in the economic environment of the country. The aim of the study is to analyze the current use of expert systems in the economic environment of the country. The research methods used in the work are as follows: search on the available methodological and scientific literature with the analysis of the found material, classification, systematization, analysis of documentation and researchers' results on the problem of the conducted study.

In the first section of our study the general questions of expert systems development are considered. The overall view of the expert system with its typical subsystems is presented. Attention is drawn to the fact that the peculiarity of expert systems is their ability to accumulate the knowledge and the experience of the most qualified experts in a narrow subject area. The properties of expert systems are analyzed in detail. The specific cases in which it is advisable to use expert systems are given. The characteristics of the tasks that are solved by them are listed.

The use of expert systems in business planning is considered. It is stated that in the conditions of economic instability the business planning processes expert system can effectively carry out marketing research for production of goods/services, draw up a financial plan of the project and ensure implementation of other business planning functions. The structure of such expert system is outlined. The importance of forming a knowledge base for such an expert system is pointed out, as well as an example of the knowledge base part of the computer expert business planning system is presented.
\end{abstract}

${ }^{1} \mathrm{PhD}$ in Economics, Associate Professor of Digital Economy and Business Analytics Department,

Lviv Ivan Franko National University, Ukraine 
The use of expert systems in production is analyzed. It is ascertained that in connection with the tasks that are set before industrial production, the following sections should be comprise in the knowledge bases: a bank of models and methods, including a list of measures for improving the management of the enterprise, and the manager of knowledge, which interprets data from the working memory of the database on the base of its logic conclusions. The main components of the expert evaluation system used at the industrial production are considered. It is emphasized that the system must retain all the preliminary reporting necessary to find out the trends in the enterprise development and the measures taken by the management in the previous periods.

The use of expert systems in financial institutions is considered. As an example of the expert systems usage in economics and finance, an expert system for credit operations and an expert system allowing to conduct mechanized or fully automated trading in the currency market are considered. The knowledge base modules of the expert system for credit operations are reflected. The specifics of the Meta Trader expert system have been clarified: all management actions of it are formed in the client terminal and sent to the server. It is noted that expert systems use to solve problems in the following areas: stock exchange trading; credit analysis; risk management; construction of loan and investment portfolios; banks' ratings assessment; audit automation; forecasting changes in the financial market.

The importance of expert systems in determining the economic security level is analyzed. The expert system "Universal Expert" is used to diagnose the economic security level of the studied economy, monitoring and forecasting object is considered. Attention is drawn to the fact that the modeling of macroeconomic security processes is inherent in the social and economic orientation of such systems. The structure of the information system for decision support in tax authorities is considered. It provides prompt decision of new tasks related to the implantation of an incentive tax system contributes to economic stability and security.

\section{Introduction}

Nowadays solving of the international problems and issues requires the widespread use of computer software. Most of these tasks are of a large amount of information, poorly formalized and require an informal solution. Expert systems are often used for these purposes. They are based on infor- 
mation within a limited field, capable to accumulate the knowledge and experience of highly qualified professionals. Expert systems are designed to solve complex problems and provide users of low professional level with high-level problem-solving tools.

The relevance of the development and the use of expert systems investigation in the field of economics is predetermine by the fact that the issues of using such systems are becoming more applicable in the context of continuous scientific and technological progress. In addition, for the continuous and successful development of the economy, the state needs to develop the IT infrastructure of companies.

According to T. Zaitseva, expert systems refer to intellectual information systems that are intended for mass use. Expert systems perform a number of functions; among them are the function of a consultant, who helps in solving a particular task, and the function of an expert, who directly solves this task [3, p. 138].

Theoretical and practical problems of relevance and prospects of expert systems development in economics have been investigated in the scientific works of such domestic and foreign scientists as N. Abdikeyev, D. Barney, T. Davenport, A. Karminskyi, B. Milner, H. Goldstein, A. Goponenko. Many scientists and practitioners have dealt with the development of intellectual, in particular expert, systems using various tools. They are A. Chastikov, D. Muromtsev and others. The amplification of intellectual systems in various fields was conducted by R. Bazhenov, M. Chvanova, V. Osadchyi, O. Lezhenko, M. Zhelnin. S. Khabarov, V. Toiskin, Yu. Telnov, V. Lytvyn, A. Kozlov and other researchers were engaged in the analysis of questions concerning the use of intellectual information systems and the means of their development.

The aim of the study is to analyze the modern application of expert systems in the economic environment of the country.

The objectives of the study are to consider the various aspects of the expert systems usage in different areas of the economic environment of the country: in business planning, in manufacturing, in financial institutions and in determining the level of the region and the state economic security.

The following research methods are used in the work: search on the available methodological and scientific literature with the analysis of the found material, classification, systematization, analysis of documentation and researchers' results on the problem of the conducted study. 
The logic of the study arrangement is based on logical patterns of thinking. That is why the general issues of expert systems development, their properties, problems of their development and usage are considered first of all. The next sections analyze various aspects of the expert systems application in different areas of the country's economic environment: business planning, manufacturing, financial institutions, and determining the level of the region and the state economic security.

\section{The main aspects of the expert systems development}

An expert system (ES) is an intelligent information system designed to solvepoorly formalized tasks, based on the experience gained by human experts in the problem area. It includes a knowledge base with a set of rules and a mechanism for inference, and allows users to identify a situation, to make a forecast, to formulate a decision, or to recommend a choice of action based on the facts provided by the user.

In general, the expert system consists of the following typical subsystems: the subsystems of knowledge acquisition that manages their classification by belonging to local expert systems; subsystems of knowledge output management that manages their output in a cluster expert system using a mathematical model of constructing a logical inference tree; conclusions and recommendations subsystems; a set of local expert systems, obtained on the basis of the knowledge decomposition in the chosen subject area (Figure 1).

A peculiarity of expert systems is their ability to accumulate knowledge and experience of the most qualified specialists (human experts) in any narrow subject area. With this knowledge, users of expert systems

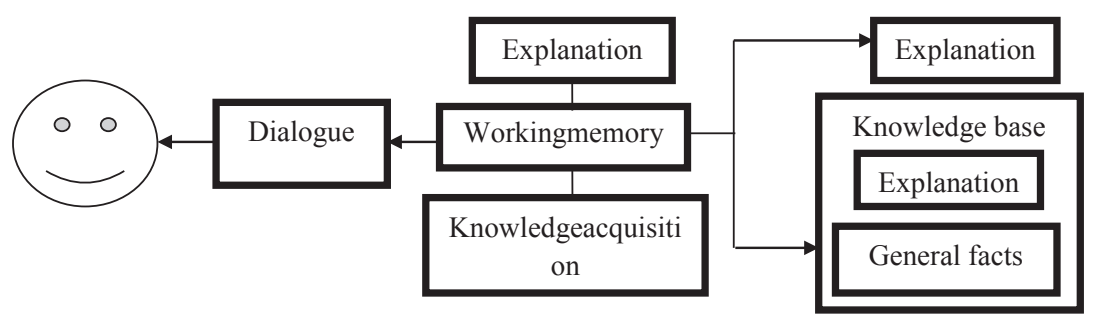

Figure 1. Scheme of the expert system 
with ordinary qualifications can solve various tasks as effectively as the experts themselves would. This effect is achieved by the fact that the expert system reproduces almost the same pattern of reasoning that is usually used by the human expert in the analysis of any problem. In this way, expert systems allow to copy and disseminate knowledge, making the unique experience of several highly qualified professionals available to a wide range of ordinary specialists [2, p. 59]. The professional level of users of expert systems can be very different. The functions of the ES also depend on the kind of user activity.

Expert systems are designed to reproduce the experience and knowledge of high-level professionals and to use this knowledge in the management process. They are developed using a fuzzy logic mathematical apparatus for application in narrow areas, since their usage requires a large amount of computer resources to process and store knowledge.

The foundation of expert systems is a knowledge base that is grounded on the models of knowledge representation. By reason of high financial costs, expert systems are not widespread in Ukrainian economic information systems. It is believed that any expert system is a knowledge-based system, but the knowledge-based system is not always an expert system. In knowledge-based systems, the rules (or heuristics) for solving problems in a particular subject area are stored in the knowledge base. Problems are posed to the system in the form of facts set that describe a situation, and the system using a knowledge base tries to deduce from these facts [1, p. 124].

The properties of expert systems that distinguish them from ordinary programs:

- accumulation and organization of knowledge about the subject area in the process of construction and operation of the expert system;

- clarity and accessibility of knowledge;

- application of high quality experience for problems solving, that corresponds the thinking level of the most qualified experts in the field, leading to creative, accurate and effective decisions;

- modeling rather than the physical (or other) nature of a particular problem area the mechanism of human thinking applied to solving problems in this problem area;

- the availability of predictive capabilities wherein the expert system issues not only the specific situation, but also shows how these responses 
change in a new situations, with the opportunity to explain in detail how the new situation has led to change;

- the provision of a new quality, such as an institutional memory, through the knowledge base, which is a part of the expert system and is developed during the interaction with specialists of the organization, and is the current policy of this group of people;

- the ability to use ES for managers' training, providing new employees with a wealth of experience and strategies to study recommended policies and methods;

- an explicit separation of management tools and data;

- solving problems with heuristic and approximate methods, which, in contrast to algorithmic ones, do not always guarantee success;

- a capacity to make symbolic decisions: the ability to convey knowledge in symbolic form and to reformulate symbolic knowledge;

- rule-based and logical decision making;

- self-awareness - the ability to examine self-made decision $\mathrm{s}$ (that is, to verify their correctness) and to explain self-made actions;

- the ability to analyze the own mistakes;

- the possibility of using incomplete or incorrect inputs;

- competence - the ability to reach the expert level of decisions (in a specific subject area have the same level of professionalism as the human experts), to be capable (to apply knowledge effectively and quickly, avoiding, like human experts, unnecessary calculations), to have adequate robustness (the ability to reduce gradually the quality of work approaching the limits of the range or competence of acceptable data reliability);

- logical adequacy - the ability to present knowledge of the expert system to recognize all the differences that are embedded in the original entities;

- heuristic capacity - the presence both the expressive presentation language and the mean of representation designed and interpreted to solve the problem with the help of ES;

- naturalness of notation - the convenience and simplicity of expressions that formally describe knowledge in the expert system, the clarity of their content, even to those who do not know how the computer interprets these expressions;

- logical transparency - the ability of an expert system to explain decision-making techniques that determine how easy it is for the staff to find out what the program does and why; 
- depth - the ability of the expert system to work in a subject area that contains difficult tasks and to use complex rules;

- utility - the ability of the expert system to identify trough the dialogue the needs of the user, identify and eliminate the causes of malfunctions, as well as solve problems;

- flexibility - the ability of the system to adapt to different users, as well as to account the changes in the qualifications of the same user;

- convenience - natural interaction with the expert system, its flexibility and resilience of the system to errors [13, p. 14].

It should be noted that the development of the ES involves some difficulties and the formulation of ways to overcome them, i.e.:

1. The problem of extracting the experts' knowledge. No one specialist will reveal the secrets of his own professional skill, unless he is interested in it. This can be a material interest, or an increase in credibility through the publication of their achievements, or a partnership in a project under development, etc.

2. The problem of expert knowledge formalization. Often experts who are specialists in a particular field are not able to formalize their knowledge at a knowledge base sufficient level. Many professionals make decisions intuitively, without thinking about the whole chain of evidence that led to the final right decision. Therefore, it is recommended to choose an expert who is able to explain the course of their thoughts even to non-professionals.

3. The expert does not have enough time. Often the chosen expert does not have the free time to impart his knowledge. In order to avoid such a situation, it is necessary to arrange in advance with a specialist for several meetings to obtain knowledge.

4. Insufficient accuracy of the rules that the expert forms when working with a knowledge engineer. To avoid such a situation, actual tasks for expert adequate decisions should be used. Besides, when communicating with an expert, it is appropriate to use a common terminology, which later should be used when filling the knowledge base.

5. Deficiency of resources. This problem is related to the considerable time spent on developing an efficient ES. Furthermore, the human factor also has a great impact on development period. You need to select the right team of developers who will know the content of their tasks and how to accomplish them. 
6. Inadequacy of tools for the task being solved. Often, the choice of a tool or model of knowledge submission does not meet the tasks that the ES must address. In this case, it is recommended that to analyze thoroughly the purpose and the list of tasks to be solved, and then select the toolkit [15, p. 106].

The use of expert systems is appropriate in the following cases: the solution of the problem should have a significant effect, for example, economic; insufficient number of experts (for example, a need for expertise in several places at the same time); unacceptable loss of time or information when transmitting information to an expert.

In addition, the tasks to be solved must have the following characteristics:

- the ability to make a solution by symbolic reasoning rather than manipulation of numbers, as is common in mathematical methods and traditional programming;

- heuristic rather than algorithmic character (heuristic rules must be used to make a decision);

- the economic impact of the tasks must justify the cost of developing the expert system, but the task must not be overly complex (it takes hours, not weeks, for making human expert decision) for ES to solve;

- practical importance [11, p. 101].

\section{Industrial Production Expert Systems}

Expert systems operate not only with data, but also with abstract conceptual knowledge expressed in the natural language and terms of the subject area. Knowledge bases serve as a form of conceptual knowledge reflection, and the conceptual knowledge itself becomes simply knowledge. The rules contained in the knowledge base are equivalent to a certain application program and may be different in format. The most appropriate is the format of the "if - then" rule, and as a component of "then" can be used conclusions, statements, assumptions, instructions, i.e. changes of the database. A rule-related condition determines whether a rule is potentially true to the current state of the situational model. This rule allows to take action if all the conditions set for it are satisfied.

The expert decision-making system at the enterprise is meant as composite software complexes that operate with knowledge in order to obtain a satisfactory and effective decision in the field of production management and planning. Such systems, like human experts, use symbolic logic and heuris- 
tics (empirical rules) to find solutions. But this artificial expertise has certain advantage over human one: it is constant, consistent, can be easily transmitted, documented, refined and supplemented. As a result, expert systems, linking computers to the wealth of human experience, increase the value of expert knowledge, make it widely used. Knowledge bases include the following main blocks: domain knowledge; knowledge of the object's development goals; knowledge of the environment; knowledge of the current state of the object; block of accumulation and adjustment of knowledge; block of logical conclusion; explanatory block; bank of domain models; control structure. However, there is a point of view that is worth to be maintained that one of the main tasks of developing expert systems to increase the efficiency of the enterprise is improving the enterprise management. To fulfil this task, it is proposed to include the following two sections in the knowledge base:

- bank of models and methods, including a list of measures to improve the management of the enterprise;

- a knowledge handler, or an interpreter that deduces data from the working memory of the database grounded on its logic [14, p. 18].

Thus, when developing an expert system, the most difficult is the problem of creating a knowledge base. The scientists propose the following procedure of the knowledge base development for the enterprise management system, which is organically constructed on usage of dialog imitation system. The scheme of this procedure is shown in Figure 2. The lower part is the dialog system; the upper part is the system for creating the knowledge base.

Such systems of are represented by advisory and audit systems; the main function of them is to evaluate the actions of the enterprise administration (manager) for the reporting period. Moreover, these systems seek the ways to improve the economic efficiency level in a given period.

As a rule, the following shall be assessed:

- flexibility of enterprise development strategy and dividend policy;

- effectiveness of the loan strategy;

- stability of the enterprise solvency.

Most of the tasks of assessing the financial condition of an enterprise and finding ways to improve it can be solved by the methods of finding the largest and smallest values of the target function (financial or production leverage, sustainability of the enterprise or its solvency, etc.). In this case, the constraints that define the search area of unknown quantities are usually linear [5, p. 219]. 


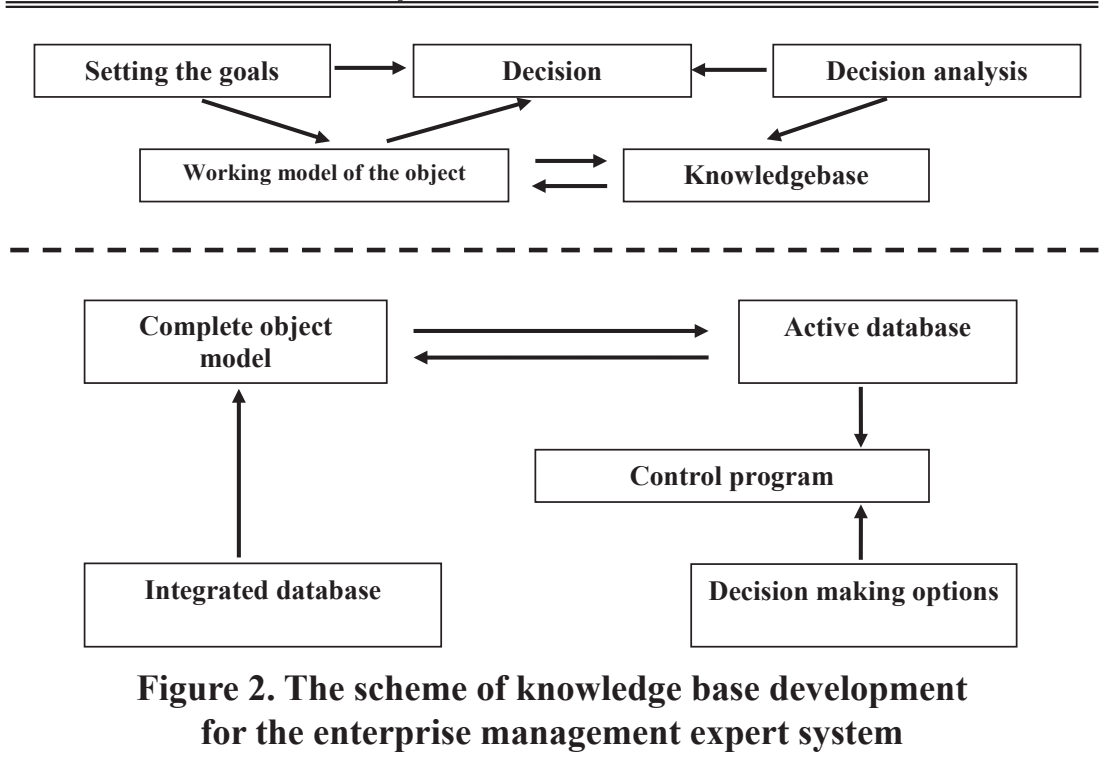

Let us consider the main components of an expert evaluation system. Fig. 3 depicts blocks designed to perform the following functions.

The local assessment unit is a set of programs designed to calculate local, i.e., little related with one another, economic indicators. Such indicators characterize only one side of a multifaceted managerial activity.

The integrated assessment unit incorporates programs that allow the calculation of many related metrics, the integrated results of which are embodied in the metrics:

- results of economic activity;

- results of financial activity;

- results of financial and economic activity.

A modified matrix of financial strategies, in combination with the decision-maker's goals tree, is the method to provide the solution search.

Data entry and correction units are standard.

Information support is created in the form of an operational database and help files. The online database contains accounting files for the current period and the help files for system settings. In particular, they are:

- the income tax rate; 


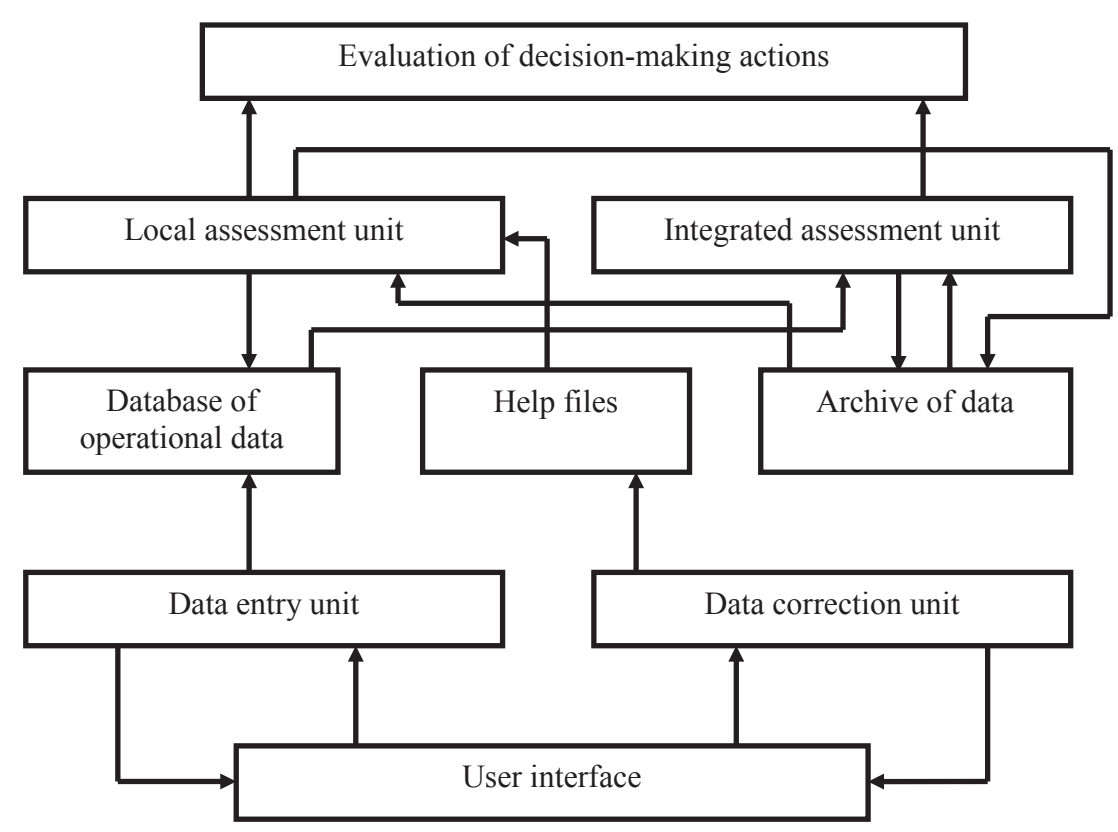

Figure 3. The main components of the expert evaluation system

- the average interest rate on the loan;

- the normative economic profitability.

In addition to the above mentioned data, the system must retain all the preliminary accounting (data archive) necessary to clarify trends in the development of the enterprise and the measures taken by management in previous periods. Thus, the use of expert systems for the analysis of economic activity significantly affects the efficiency of management and the effectiveness of the enterprise functioning in general [16, p. 81].

\section{Financial Institutions Expert Systems}

Examples of the expert systems usage in economics and finance are the expert system for credit operations and the expert system to conduct mechanized or fully automated trading at the currency market. 
In the expert system for credit operations knowledge of three types is used. The most important of these is knowledge about customer security. The different types of security are divided into three categories. Deposits are the first class security. Cash is an example of second-class collateral, and pledge security is classified as illiquid. Knowledge of the client's financial status is very important. The two most important determinants of a customer's financial characteristic are their own funds and current gross sales. The third category of knowledge is about the expected income of the bank. According to this knowledge, three modules of the knowledge base are formed: security, financial position and income of the bank [6, p. 62]. In this case, the inference machine operates with the production rules of the following form (Table 1).

Table 1

Knowledge base modules of expert system for credit operations

\begin{tabular}{|c|c|c|c|}
\hline Security & $\begin{array}{c}\text { Financial } \\
\text { conditions }\end{array}$ & Income & Conclusion \\
\hline Excellent & Good & Acceptable & Give a credit \\
\hline Good & Good & Acceptable & $\begin{array}{c}\text { It is recommended to obtain } \\
\text { additional customer information }\end{array}$ \\
\hline Moderate & Average & Insufficient & Refuse a credit \\
\hline
\end{tabular}

Of particular interest are the programs (experts, scripts and custom indicators) that allow conducting mechanized or fully automated trading in the currency market and significantly expanding trading information support.

The technical peculiarity of trading in the currency market is characterized by the use of the Meta Trader information and trading system. All managed operations in this expert system that are generated in the client terminal and sent to the server. Applications (expert, script, indicator) can work only within the client terminal, only if it is connected to the server (dealing center). No applications are installed on the server.

The client terminal is a part of the information and trading system; it also includes a server that is installed in the dealership. The dealership itself has the means to communicate with other market participants, such as banks and financial institutions.

The client terminal has an information environment. That is a set of parameters that inform about the state of the market and the relationship 
between the trader and the dealing center. It contains information on current prices, restrictions on the minimum and maximum order size, the minimum distance of stop orders, the permission / prohibition of automatic trading and many other useful parameters that characterize the current situation. The information environment is updated as new data arrives at the terminal.

The structure of such an expert system is as follows:

1.Pre-treatment unit. This unit is responsible for analyzing the output. If the output satisfies the conditions laid down in the knowledge base of the expert system, then the unit correctly completes its work and transfers control to the unit of open transactions accounting. If the output data does not satisfy the conditions, then the unit stops working and displays an error message.

2. Unit of open transactions accounting. This block counts the number of open positions. If there are more than two open transactions, the block displays a termination message and closes.

3. Unit of trade criteria definition. This unit is the knowledge base of the expert system. It contains all the trade rules necessary to make the right decisions. The main task of this unit is to analyze the data entering the system. If the received data meets the rules laid down in the knowledge base of the system, then the control is transmitted to the unit of transactions' opening.

4. Unit of transactions' opening (closing). This unit performs a single simple function. When a signal is received to open (close) an agreement, the unit produces an open (close) position. If the error is not insurmountable, then a retry is attempted, if the error is critical, then the expert terminates

5. Error handling unit. If any unit has finished its work incorrectly, the control is transferred to the error handling unit. An error analysis is performed here. If the error is not insurmountable, then a retry is attempted, if the error is critical, then the expert terminates [12, p. 42].

Expert systems have been successfully used in areas where both standard algorithmic methods based on accurate calculations as well as knowledge and experience of specific expert analysts are used, and decision making is formed in the context of incomplete data and depends on qualitative rather than quantitative estimates. These subject areas include, first of all, the area of financial activity analysis, where the effectiveness of the decisions made depends on the comparison of many different factors, accounting for com- 
plex cause and consequence relationships, application of non-trivial logical considerations, etc. Thus, many firms operating on the New York Stock Exchange use expert systems to solve problems in the following areas: stock exchange trading; credit analysis; risk management; construction of loan and investment portfolios; estimation banks' ratings; audit automation; forecasting changes in the financial market. The use of such expert systems by business entities will allow them to have effective tools for business plans creation and implementation of them in various projects.

\section{Economic Security Expert systems}

Determining of economic security at the state, the region or the enterprise level significantly influences the decision making. Since calculations of the economic security level require processing a large amount of data, it is crucial to create software complexes, databases, expert systems that would reflect the economic entities characteristics of different hierarchical levels for which calculations are made, and would accumulate data from previous periods for the purposes to analyze the situation and predict it.

Economic expert systems require the creation of a database that stores a great deal of information: planned, factual, reporting and other data. The developed expert system "Universal expert" belongs to the combined type of expert systems. It can be used to diagnose the economic security level of the studied object of economy, monitoring or forecast. The expert system consists of a knowledge base containing the following components: knowledge of the language of communication for the linguistic processor; knowledge about the processes of solving the problem and providing expert opinions for the process interpreter; knowledge about the ways of interpreting knowledge for the module of knowledge search; additional knowledge about decision making for the module providing the expert conclusions (Figure 4).

The expert system also has a unit of explanations for the user and comments on the expert system's actions. The explanation unit was created as a help system for the user. It is suggested the user communicate with the expert system in a dialog mode. The user responds to a list of issues related to economic security, identified by the expert and included in the expert system. The algorithm determines the economic security level of the studied object and provides an expert opinion on the economic security status [7, p. 42]. 


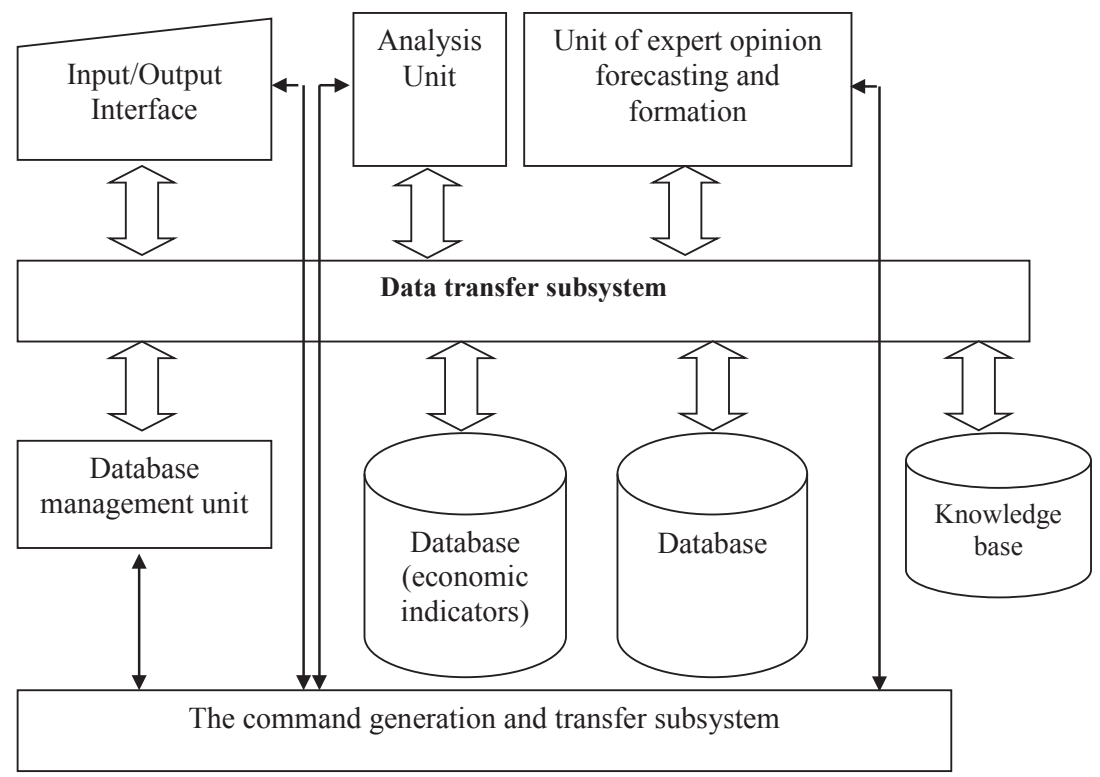

Figure 4. Scheme of the expert system «Universal expert»

The expert system allows to supplement the knowledge base, to add separate functions for carrying out additional calculations and refinements, to update the existing methods of calculating the level of economic security, to add forecast models for obtaining predictable results. In order to achieve the predicted level of the object' economic security under investigation, it is desirable to conduct an analysis of the economic security status over several related periods to identify current trends.

The study of the economic security state at the region or the enterprise level is carried out by its main functional components. As a result of the conducted research, the following functional components of economic security at the regional level were identified: financial, foreign economic, investment and innovative, energy, social and demographic, technical and technological, environmental, food.

The user of the expert system through the user interface enters data on the enterprise, region or state according to the level at which the economic 
security assessment is carried out (answering the questionnaires, which are pre-filled by the expert). All these answers and data are subsequently stored and accumulated in the database. Then the user selects the components to assess the level of economic security and fills in the data for forming the evaluation matrix, which is already embedded in the expert knowledge base. Further, the expert system analyzes the obtained results and provides the user with an expert opinion, which, based on a retrospective analysis of the studied economic object state, determines its development trends, assesses the current level of economic security and provides a forecast of economic security state (the possibility of obtaining the short-term results forecast for one, two or three years is laid). On the request of the user, additional information about possible investment and innovation programs can be entered and predictive data on the feasibility of their application in the context of ensuring the economic security of the enterprise, the region or the state can be acquired.

Modeling the processes of ensuring macroeconomic security has some peculiarities related to the social and economic orientation of such systems development. That is, the assessment of the economic security level is influenced by both social factors (the level of population well-being, the provision of high employment, the degree of satisfaction of needs, the demographic and environmental situation) and purely economic (the level of production, the dynamics of basic economic indicators, the resource availability). It should be noted that social and economic factors are characterized by mutual influence and to a certain extent determine the mutual level of development.

Developing the methodology for stimulating economic growth by tax methods, S. Mishchenko proposed the structure of an information system for supporting decision-making in tax authorities, which provides prompt solutions to new problems related to the introduction of a stimulating tax system to improve efficiency and accuracy of the work. The analysis of the existing approaches to the complex economic objects information analytical systems construction allows proposing the scheme of the economic security information analytical complex [9, p. 11].

It is also necessary to take into account the fact that the development of economic systems at the macro level, and, consequently, the management of economic security processes must be considered at the level of intercon- 
nections, i.e. relations with higher-level systems, and at the intersystem one, i.e. the level of relations with subsystems [7, p. 47].

Formation of quantitative estimates of the economic security level obtained on the basis of modeling methods, unlike expert estimates, allows to solve the problems of forecasting, planning and managing the complex macroeconomic systems development (Figure 5).

The expert system provides an opportunity to assess the threats level of the economic region security and to rank them. At this stage, it is particularly important to have objective, complete, comprehensive information on the social and economic situation at the national and regional levels, as well as on the extent of priority national interests implementation in the economic, social, innovation spheres defined at the legislative level.

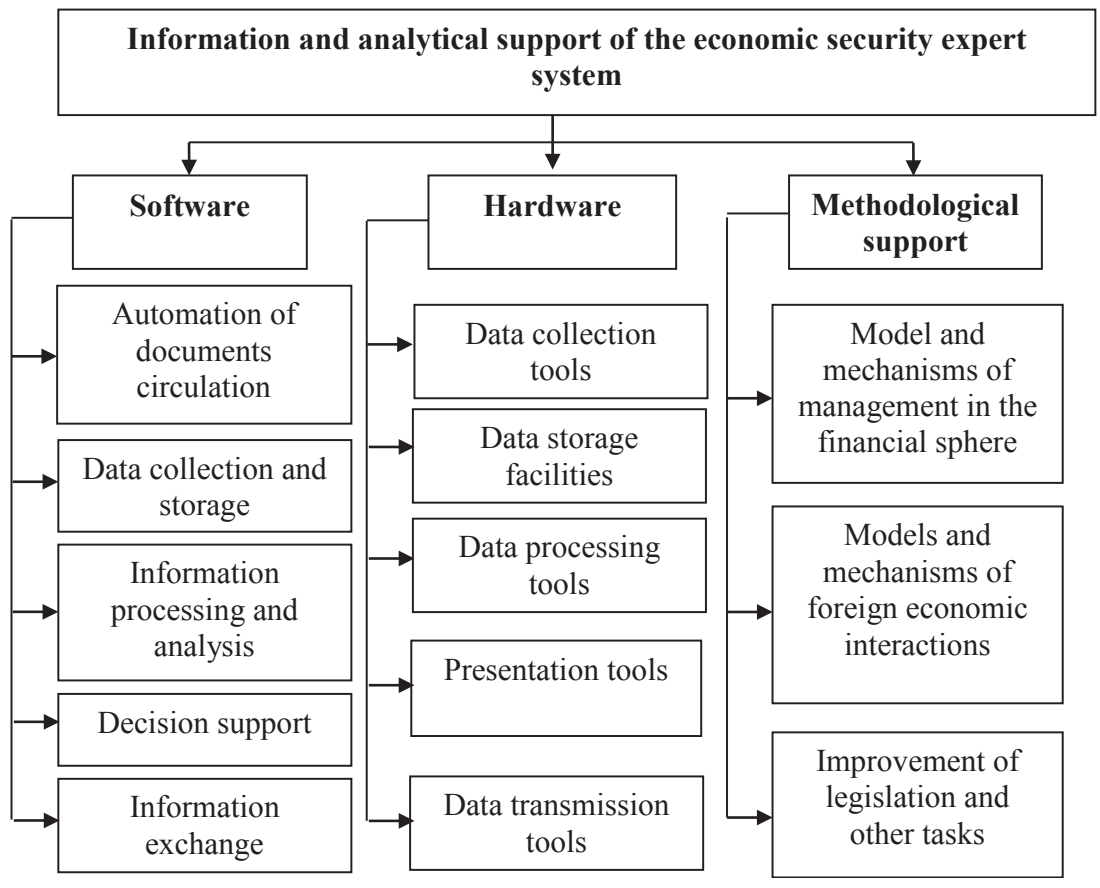

Figure 5. Types of information and analytical support of the economic security expert system 
The monitoring involves analysis of the economic situation, identification of social and economic, innovation and investment regions and state development tendencies, assessment of the threats level to economic security.

The study of the level of economic security is carried out on the selected main subsystems, which allows to determine not only its overall importance, but also to identify the problematic components of economic security and the factors that cause threats to the economic activity of the enterprise. If the user enters additional information about the financial state of the enterprise, the expert system evaluates the possibility of implementing the chosen strategic direction of the economic object development and provides recommendations for a specific development program. The expert system provides an opportunity to predict the expected risks to the economic security level [10, p. 74].

Thus, increasing the amount of information that comes directly to executives, the complexity of the tasks at hand, the need to take into account a large number of interrelated and interdependent factors, and the fast-paced environment, increasingly require the use of information technology in decision-making in various economic structures. The technology of expert systems in the economic field is more practical and gives better decisions than conventional decision-making systems.

\section{Conclusions}

Summarizing all of the above, we have made the following overviews:

1. In the first section of our study the general questions of expert systems development are considered. The overall view of the expert system with its typical subsystems is presented. Attention is drawn to the fact that the peculiarity of expert systems is their ability to accumulate the knowledge and the experience of the most qualified experts in a narrow subject area. The properties of expert systems that distinguish them from ordinary programs are analyzed in detail. It is noted that the development of the ES is subject to some difficulties and the ways to overcome these problems are outlined. The specific cases of expert systems usage are given, as well as the characteristics of the tasks they solve.

2. The use of expert systems in business planning is considered. It is noted that the modern economy business planning is an integral part of the functioning of any business entity, and for its successful activity it is necessary to have 
a modern business process management system as a tool. It is stated that in the conditions of economic instability the business planning processes expert system can effectively carry out marketing research for production of goods/ services, draw up a financial plan of the project and ensure implementation of other business planning functions. The structure of such expert system is outlined. The importance of forming a knowledge base for such an expert system is pointed out, as well as an example of the knowledge base part of the computer expert business planning system is presented.

3. The use of expert systems at industrial production is analyzed. It is stated that the expert decision-making system at the enterprise is a composite software complexes that operate with knowledge in order to obtain a satisfactory and effective decision in the field of production management and planning. It is ascertained that in connection with the tasks that are set before industrial production, the following sections should be comprise in the knowledge bases: a bank of models and methods, including a list of measures for improving the management of the enterprise, and the manager of knowledge, which interprets data from the working memory of the database on the base of its logic conclusions. The main components of the expert evaluation system used at the industrial production are considered. It is emphasized that the system must retain all the preliminary reporting that is necessary to find out the trends in the enterprise development and the measures taken by the management in the previous periods.

4. The use of expert systems in financial institutions is considered. As an example of the expert systems usage in economics and finance, an expert system for credit operations and an expert system that allows to conduct mechanized or fully automated trading in the currency market are considered. The knowledge base modules of the expert system for credit operations are considered. The specifics of the Meta Trader expert system have been clarified: all management actions of it are formed in the client terminal and sent to the server. The units of such expert system are considered. It is noted that expert systems use to solve problems in the following fields: stock exchange trading; credit analysis; risk management; construction of loan and investment portfolios; banks' ratings assessment; audit automation; forecasting changes in the financial market.

5. The importance of expert systems in determining the economic security level is analyzed. The expert system "Universal Expert", which belongs to 
the combined type of expert systems and is used to diagnose the economic security level of the studied economy, monitoring and forecasting object, is considered. It is stated that the expert system allows to supplement the knowledge base, to add separate functions for carrying out extra calculations and refinements, to update the existing methods of calculating the economic security level, to add predictive models for obtaining forecast results. Attention is drawn to the fact that the modeling of macroeconomic security processes is inherent in the social and economic orientation of such systems. The structure of the information system for decision support in tax authorities is considered, which provides prompt decision of new tasks related to the implantation of an incentive tax system contributes to economic stability and security.

Further research should be focused on studying the experience of expert systems implementation in various spheres of developed countries economic environment and application of the best achievements in our country.

\section{References:}

1. Bljumin S.L., Shujkova L.A. (2001). Modeli i metody prinjatija reshenij v uslovijah neopredelennosti [Model sanddecision-making method sinconditions of uncertainty ]. Lipeck: LJeGI. (in Russian)

2. Hlybovets M.M., Oletskyi O.V. (2002). Shtuchnyiintelekt: pidruchnykdliastud. vyshch. navch. zakladiv, shchonavch. zaspets. "Komp'iuterninauky» ta «Prykladnamatematyka» [ArtificialIntelligence: A Textbook for Students. higher. teach. Institution sthatteach. For spec. Computer Science and Applied Mathematics]. Kyiv: Akademiia. (in Ukrainian)

3. Zajceva T.V. Nesterova E.V., Igrunova S.V., i dr. (2011). Razrabotka i sozdaniej ekspertnoj sistemy dlja vybora vida obsluzhivanija IT - infrastruktury predprijatija [Development and creation of an expert system for choosing the type of IT infrastructure maintenance of the enterprise]. Nauchnye vedomosti Belgorodskogo gosudarstvennogo universiteta. Serija: Jekonomika. Informatika, vol. 20 , no. $19-1$, pp. $138-150$.

4. Zheleny M. (2002). Informacionnye tehnologii v biznese [Information technology in business]. SPb.: Piter. (in Russian)

5. Kuznecov N.A., Kul'ba V.V., Kosjachenko S.A. i dr. (2004). Optimal'nye modul'nye sistemy real'nogo vremeni (analiz $i$ sintez) [Optimal modul arreal-timesystems (analysis and synthesis)]. Moskva: IPPIRAN, 2004. (in Russian)

6. Lezhenko A.I., Kuznecov I.A., Kuznecov S.K. (2012). Ispol'zovanie jekspertnyh sistem dlja intellektual'nogo analiza dannjah [Using expert systems for datamining]. Informacionnye tehnologii i vychislitel'nye sistemy, no. 1, pp. 60-64.

7. Loiko V.V., Loiko D.M. (2015). Ekspertna systema yak instrument vyznachennia rivnia ekonomichnoi bezpeky [Expert systemas a tool for determining the level of economic security]. Naukovo-tekhnichna informatsiia, no. 3, pp. 41-46. 
8. Lysenko Ju.G., Zaharchenko V.Ju. (2012). Predposylki primenenija informacionno-analiticheskih sistemu pravlenijaj ekonomicheskoj bezopasnost'ju [Prerequisites for the application of informationandanalytical systems for managing economic security]. Naukovi paci NDFI, no. 3(60), pp. 44-49.

9. Mishhenko S.G. (2006). Sistemy podderzhki prinjatija reshenij v stimulirujushhej sistem enalogooblozhenija [Decisions upport systems in anincentivetax system]. Novoe v jekonomicheskoj kibernetike. Metody, modeli, prikladnye zadachi prinjatija reshenij, no. 4, pp. 5-16.

10. Moiseenko E.V., Lavrushina E.G. (2004). Informacionnye tehnologii v jekonomike [Information Technology in Economics]. Vladivostok: Izdatel'stvo VGUJeS. (in Russian)

11. Serebrjakova T.A., Klimovich T.M. (2017). Celesoobraznost' razrabotki i ispol'zovanijaj ekspertnyh sistem dlja jekonomicheskih struktur [Feasibility of developing and using expert systems for economic structures]. Uchenye zametki TOGU, vol. 8, no. 1, pp. 100-103.

12. Stepanov O.A. (2010). Jekspertnaja sistema kontrolja i upravlenija torgovlej na valjutnom rynke [Expert system of control and management of trade in the foreign exchange market]. XLIII Kraevaja nauchnaja studencheskaja konferencij apo matematike $i$ komp'juternym naukam, sbornik materialov. Krasnojarsk: Sibirskij federal'nyjun-t, pp. 41-42.

13. Subbotin S.O. (2008). Podannia y obrobkaznan u systemakh shtuchnoho intelektu ta pidtrymky pryiniattia rishen: Navchalnyi posibnyk [Knowledge submissionand processing in artificial intelligence systems and decision support: A textbook]. Zaporizhzhia: ZNTU. (in Ukrainian)

14. Sumenkov M.S., Sumenkov S.M. (2003). Jekspertnye sistemy priprinjatii reshenij na predprijatii [Expert systems for making decisions at the enterprise]. Biznes, menedzhment i pravo, no. 2, pp. 16-22.

15. Sharov S.V., Hrustal'ov S.O. (2016). Instrumental'ni zasobi ta etapi rozrobki ekspertnih sistem [Tools and stages of development of expert systems]. Zbirnik naukovih prac' Harkivs 'kogo nacional'nogo universitetu Povitrjanih Sil, no. 4, pp. 105-109.

16. Shorikov A.F., Bucenko E.V., Krylov V.G. (2016). Tehnologija razrabotki komp'juternoj jekspertnoj sistemy biznesplanirovanija [Technology of development of computer expert system of business planning]. Vestnik Permskogo Nauchnogo Centra, no. 2, pp. 78-82.

17. Shorikov A.F., Bucenko E.V. (2013). Jekspertnaja sistema investicionnogo proektirovanija [Expert system of investment design]. Prikladnaja informatika, no. 5(47), pp. 96-104. 